Pflügers Arch (1993) 424:403-409

\title{
Furosemide stimulates renin expression in the kidneys of salt-supplemented rats
}

\author{
Barbara Modena ${ }^{1}$, Stephan Holmer ${ }^{2}$, Kai-Uwe Eckardt ${ }^{3}$, Karin Schricker ${ }^{3}$, Günter Riegger ${ }^{2}$, \\ Brigitte Kaissling ${ }^{1}$, Armin Kurtz ${ }^{3}$ \\ ${ }^{1}$ Anatomisches Institut der Universität Zürich, Switzerland \\ ${ }^{2}$ Medizinische Klinik und Poliklinik II der Universität Regensburg, Germany \\ ${ }^{3}$ Physiologisches Institut der Universität Regensburg, Germany
}

Received March 23, 1993/Received after revision May 5, 1993/Accepted June 3, 1993

\begin{abstract}
This study was conducted to obtain information about a possible influence of salt transport by the thick ascending limb of Henle (TALH) and the macula densa on the expression of renin in the kidney. To this end, adult male rats were subcutaneously infused with furosemide $(12 \mathrm{mg} / 24 \mathrm{~h})$, an established inhibitor of TALH and macula densa salt transport, or with vehicle for 6 days. The animals had free access to chow, water and salt water $(0.8 \% \mathrm{NaCl}, 0.1 \% \mathrm{KCl})$ to maintain salt and water balance. Chronic furosemide treatment led to a 20 -fold increase in urine flow rates and $50 \%$ increase in kidney weights, while urine osmolality decreased by $60 \%$ and body weight gain decreased by $40 \%$ in the furosemide-treated animals. Plasma renin activities increased from $2.9 \pm 0.5 \mathrm{ng}$ angiotensin $\mathrm{I} \mathrm{h}^{-1} \mathrm{ml}^{-1}$ in controls to $10.6 \pm 2.2 \mathrm{ng}$ angiotensin $\mathrm{I} \mathrm{h}^{-1} \mathrm{ml}^{-1}$ in furosemide-treated rats. In parallel, kidney areas immunoreactive for renin increased by $80 \%$ and the renal content of renin mRNA increased by $120 \%$ in the animals receiving furosemide. Under the assumption that the effects seen on renal renin expression were primarily due to the inhibition of TALH and macula densa function by furosemide, our findings suggest that salt transport across the TALH and macula densa exerts a negative control function not only on the secretion but also on the expression of renin in the kidney.
\end{abstract}

Key words: Juxtaglomerular cells - Macula densa Renin secretion

\section{Introduction}

The late thick ascending limb of Henle (TALH) including the macula densa is considered to play an important role in the regulation of renin secretion, an effect that is thought to be mediated by the $\mathrm{NaCl}$ transport of these

Correspondence to: A. Kurtz, Physiologisches Institut, Universität Regensburg, Postfach 101042, D-93040 Regensburg, Germany structures $[8,24,28]$. Thus it has been demonstrated that renin secretion from a single juxtaglomerular apparatus is inversely related to the concentration of sodium chloride in the tubular fluid facing the macula densa $[17,26]$. Moreover, it is well established that acute application of loop diuretics that also inhibit salt transport by the macula densa cells [24] enhance renin secretion both in vivo (for review [15]) and in vitro at the level of the juxtaglomerular apparatus [17], suggesting that salt transport by the thick ascending limb and macula densa somehow inhibits the exocytosis of renin from neighbouring juxtaglomerular cells.

There is already evidence for a concordant regulation of renin secretion and the expression of renin by certain factors such as the intrarenal blood pressure $[20,23]$ or hormones like adrenaline [7] or angiotensin II [12, 25]. However, cell culture studies with juxtaglomerular cells have also revealed that there is no general coupling between the secretion and the synthesis of renin [16]. In view of these findings the question arises whether the macula densa has, apart from its well-established influence on renin secretion, a regulatory role for the expression of renin in the kidneys. This question is as yet unanswered. A study with hydronephrotic kidneys devoid of tubules and macula densa structures has shown that the content of renin mRNA drops to about $25 \%$ of that of the respective control kidneys [1]. However, it is difficult to evaluate from these experiments whether the change of renin mRNA was due to the lack of macula densa structures or to other structural and functional changes in the hydronephrotic kidneys.

A different approach to inhibiting macula densa function is the inhibition of salt transport by loop diuretics such as furosemide [24]. In fact, bolus injections of furosemide in combination with a low-salt diet have been used to induce severe salt depletion and extracellular volume contraction. Under these experimental conditions renal mRNA levels were found to increase 2- to 12 -fold [1, 10, 18]. Again it is difficult to evaluate a possible role of the macula densa in the regulation of renin expression from these experiments for two rea- 
sons. First, the bolus injections of furosemide were usually stopped several days before sacrifice of the animals. Secondly, extracellular volume contraction induced by furosemide treatment is likely also to influence the expression of renin via the baroreceptor mechanism or via activation of sympathetic nerves. This rather complex situation is even further complicated by the results of a recent study investigating the time course of the effect of furosemide on plasma renin activity and renal renin mRNA levels. There it was found that a bolus of furosemide led to a rise of renin mRNA levels after $2-4 \mathrm{~h}$ in rats that were pretreated with deoxycorticosterone and kept on high-salt diet [4]. In rats fed a normal-salt diet, however, no effect of furosemide on renal renin mRNA levels was found within $16 \mathrm{~h}$, while plasma renin activity had signficantly increased [4].

To assess the influence of salt transport by the thick ascending limb and macula densa on renin gene expression it appeared reasonable to us to study the effect of furosemide in animals with unchanged salt balance. It has been shown recently that this situation can be established with rats that are chronically infused with furosemide and that have free access to salt and water [13].

Utilizing this animal model we found a $80 \%$ increase in renin-positive areas in the kidneys and a $120 \%$ increase of the renal renin mRNA content upon infusion with furosemide. These findings are compatible with the idea that salt transport by the TALH including the macula densa exerts a tonic inhibitory influence on renin expression in the kidneys.

\section{Materials and methods}

Animals. Twenty male Wistar rats (Ivanovas, Kisslegg, Germany) weighing $140-160 \mathrm{~g}$ were kept in metabolic cages. They were fed standard chow and two bottles of drinking solution were equally available, one containing tap water, the other a salt solution of $8 \mathrm{~g}$ / $1 \mathrm{NaCl}$ and $1 \mathrm{~g} / \mathrm{K} \mathrm{KCl}$. Body weight, drinking input, urinary output and urine osmolality were measured every day. For the first 4 days of the experiment all animals were kept under the same conditions. On the 5th day osmotic pumps (2 ML1; Alzet, Paolo Alto, USA) were implanted subcutaneously under the skin of the neck. In ten control animals the pumps were filled with $9 \mathrm{~g} / \mathrm{l} \mathrm{NaCl}$; in ten furosemide-treated animals the pumps contained $2 \mathrm{ml}$ Dimazon (Hoechst AG, Frankfurt, Germany) equivalent to $50 \mathrm{mg} / \mathrm{ml}$ furosemide. The delivery rate of the pumps was $10 \mu \mathrm{l} / \mathrm{h}$, thus the daily dosage of furosemide was $12 \mathrm{mg} / \mathrm{animal}$. The capacity of the pumps had been designed for 7 days. To guarantee a constant drug effect during the experiment, the pumps were primed in vitro for at least $4 \mathrm{~h}$ before implantation and the experiment was ended on the 6th day after implantation.

Processing of the kidneys. Five animals of each group were processed for determination of plasma renin activity and assay of renal renin mRNA. To this end animals were sacrificed by cervical dislocation, blood was collected from the abdominal aorta for determination of plasma renin activity and both kidneys were rapidly removed, weighed, cut in half and frozen in liquid nitrogen for extraction of total RNA. The five other rats of each group were used for immunohistochemistry and morphological examination. For this, the animals were anaesthetized by sodium thiopentobarbital (Trapanal; Byk Gulden, FRG), $100 \mathrm{mg} / \mathrm{kg}$ intraperitoneally, and the kidneys were fixed by vascular perfusion via the abdominal aorta with a buffered solution containing $25 \mathrm{~g} / \mathrm{l}$ paraformaldehyde and $1 \mathrm{~g} / \mathrm{l}$ glutaraldehyde, as described previously [6].
For immunohistochemistry at least five pieces of each kidney, comprising the cortex and the outer medulla, were shock-frozen in liquid propane. From each piece five to seven serial sections of $5 \mu \mathrm{m}$ thickness were cut in a cryostat. The serial sections of each tissue block were placed on one slide and were stained for renin using a polyclonal rabbit antiserum against rat renin, diluted $1: 10000$. Binding sites of the primary antibodies were visualized using a secondary biotinylated goat anti-(rabbit Ig) serum (SPA, Milano, Italy) and Streptavidin-Texasred (Amersham Int.), both diluted $1: 100$ in phosphate-buffered saline. One section per slide was used for quantification. Thus per animal a total of five or six sections, each from a different tissue block, were evaluated.

The slides were coded and analysed in a microscope (Polyvar, Reichert-Jung, Austria) and the renin-positive areas were quantified. For that purpose the sections were studied by epifluorescence, at a magnification of $250 \times$ and $400 \times$ in the microscope. 'The microscopic image was superimposed by a square grid [29] via a drawing tube. The grid consisted of perpendicular lines with a spacing of $1 \mathrm{~mm}$. The distance of the lines seen in the microscope corresponded to a distance of $5 \mu \mathrm{m}$ in the tissue, the area covered by the grid on the tissue corresponded to $0.25 \mathrm{~mm}^{2}$. The total surface area of measurement per kidney was $20.6 \pm 3.5 \mathrm{~mm}^{2}$ (mean $\pm \mathrm{SD}$ ), determined by the number of grid intersections falling onto the evaluated tissue area. Within this area all glomeruli with a vascular pole, defined by showing the contact of at least one glomerular arteriole with the glomerular hilus, were counted and the number of renin-positive and negative vascular poles was recorded. The total number of vascular poles encountered in each area evaluated was $111 \pm 15$ (mean $\pm \mathrm{SD}$ ). The number of intersections of the grid falling on all renin-immunoreactive areas (including all renin-positive areas in arterioles, distant from the vascular pole) and the surface density of renin-positive areas were calculated [29]. The sum of the renin-positive areas measured per kidney, divided by the respective number of vascular poles, including those without visible immunoreactivity, was called the reninindex.

\section{Determination of preprorenin $m R N A$}

Total RNA was extracted from the right kidneys, which were stored at $-70^{\circ} \mathrm{C}$, according to the protocol of Chirgwin [5], by homogenization in $18 \mathrm{ml}$ guanidine thiocyanate ( $4 \mathrm{~mol} / \mathrm{l}$ ) containing $0.5 \% \mathrm{~N}$-dodecyl sarcosinate, $10 \mathrm{mmol} / \mathrm{l} \mathrm{EDTA}, 25 \mathrm{mmol} / \mathrm{l}$ sodium citrate and $700 \mathrm{mmol} / \mathrm{l}$ 2-mercaptoethanol with a Polytron. homogenizer and by subsequent purification on a caesium chloride gradient. To this end the homogenate was layered onto a cushion of $5.7 \mathrm{~mol} / 1 \mathrm{CsCl}$ and $100 \mathrm{mmol} / 1$ EDTA and centrifuged for $20 \mathrm{~h}$ at $33000 \mathrm{rpm}$. After centrifugation RNA pellets were resuspended in $300 \mu 110 \mathrm{mM}$ TRIS $\mathrm{pH} 7.5,1 \mathrm{mmol} / \mathrm{l}$ EDTA containing $1 \mathrm{~g} / \mathrm{l}$ sodium dodecyl sulphate (SDS), precipitated with $3 \mathrm{~mol} / \mathrm{l}$ sodium acetate $(0.1 \mathrm{vol})$ and ethanol $(3 \mathrm{vol})$ and stored at $-70^{\circ} \mathrm{C}$ prior to analysis. Renin mRNA was measured by RNase protection as described for erythropoietin [22]. A preprorenin cRNA probe containing 296 base pairs of exons I and II, generated from a pSP64. vector carrying a PstI-KpnI restriction fragment of a rat preprorenin cDNA [3] was generated by transcription with SP6 RNA polymerase (Amersham Int., Amersham, UK). Transcripts were continuously labelled with $\left[\alpha-{ }^{32} \mathrm{P}\right] \mathrm{GTP}(410 \mathrm{Ci} / \mathrm{mmol}$; Amersham International) and purified on a Sephadex G50 spun column. For hybridization total kidney RNA was dissolved in a buffer containing $80 \%$ formamide, $40 \mathrm{mmol} / 1$ 1,4-piperazinediethanesulphonic acid (PIPES), $400 \mathrm{mmol} / \mathrm{l} \mathrm{NaCl}, 1 \mathrm{mmol} / 1$ EDTA pH 8. A 20- $\mu \mathrm{g}$ sample of RNA was hybridized in a total volume of $50 \mu \mathrm{l}$ at $60^{\circ} \mathrm{C}$ for $12 \mathrm{~h}$ with $5 \times 10^{5} \mathrm{cpm}$ radiolabelled renin probe. Digestion with RNase $\mathrm{A}$ and $\mathrm{T} 1$ was carried out at $20^{\circ} \mathrm{C}$ for $30 \mathrm{~min}$ and terminated by incubation with proteinase $\mathrm{K}(0.1 \mathrm{mg} / \mathrm{ml})$ and $\operatorname{SDS}(4 \mathrm{~g} / \mathrm{l})$ at $37^{\circ} \mathrm{C}$ for $30 \mathrm{~min}$. Protected renin mRNA fragments were purified by phenol/chloroform extraction, ethanol precipitation and subsequent electrophoresis on a denaturing $100 \mathrm{~g} / 1$ polyacrylamide gel. After autoradiography of the dried gel at $-70^{\circ} \mathrm{C}$ for $1-2$ 


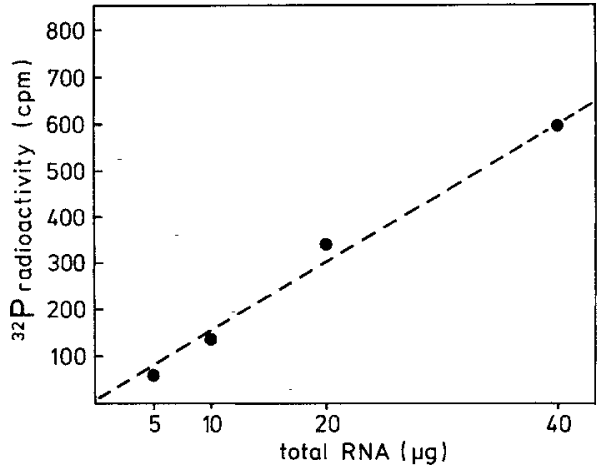

Fig. 1. RNase protection assays for rat renin mRNA using different amounts of total RNA from the standard pool of kidney RNA. After autoradiography the bands were excised and the ${ }^{32} \mathrm{P}$ radioactivity was determined by $\beta$-scintillation counting

days, bands representing protected renin mRNA fragments were excised from the gel and radioactivity was counted with a liquid scintillation counter (1500 Tri-CarbTm, Packard Instrument Company, Downers Grove, Ill., USA). The amount of radioactivity obtained from each sample of total kidney RNA was expressed relative to an external renin mRNA standard included in each hybridization consisting of $20 \mu \mathrm{g}$ pooled RNA extracted from the 12 kidneys of six normal Sprague Dawley rats. Figure 1 shows the results of an RNAase protection assay for renin mRNA using different amounts of the pooled RNA as standard.

Determination of actin $m R N A$. The abundance of rat cytoplasmatic $\beta$-actin mRNA in total RNA isolated from the kidneys was determined by RNase protection assay exactly as described for preprorenin. An actin cRNA probe containing the 76-nucleotide first exon and around 200 base pairs of surrounding sequence was generated by transcription with SP6 polymerase from a pAM19 vector carrying a Aval/HindIII restriction fragment of actin cDNA [22]. For one assay $2.5 \mu \mathrm{g}$ RNA was hybridized under the conditions described for the determination of renin mRNA.

Plasma renin activity (PRA) was determined utilizing a commercially available radioimmunoassay kit for angiotensin I (Sorin Biomedica, Düsseldorf, Germany).

Urine osmolality was measured with an osmometer (Roebling, Switzerland).

Statistics. Student's unpaired $t$-test was used for interindividual comparisons. $P<0.05$ was considered significant.

\section{Results}

The chronic subcutaneous infusion of furosemide was still effective after 6 days of treatment as indicated by the high urine flow rates, which increased from $4.6 \mathrm{ml} /$ day in controls to $90.2 \mathrm{ml} /$ day in furosemide-treated animals (Fig. 2 C), while urine osmolality decreased from $1355 \mathrm{mosmol} / \mathrm{kg}$ in controls to $485 \mathrm{mosmol} / \mathrm{kg}$ in furosemide-infused rats (Fig. 2 D). Even under furosemide the animals increased their body weights during the 6 days of treatment, the body weight gain being $60 \%$ of that found in control animals (Fig. 2 A). In contrast to the slow-down of growth, the kidney mass strikingly increased during furosemide treatment (Fig. 2 B). While vehicle-infused animals had body weights and total kidney masses (of 2 kidneys) of $176 \pm 4 \mathrm{~g}$ and 1.43 $\pm 0.14 \mathrm{~g}$ respectively, at the end of the 6 days of infusion, total kidney mass values of $2.16 \pm 0.08 \mathrm{~g}$ were

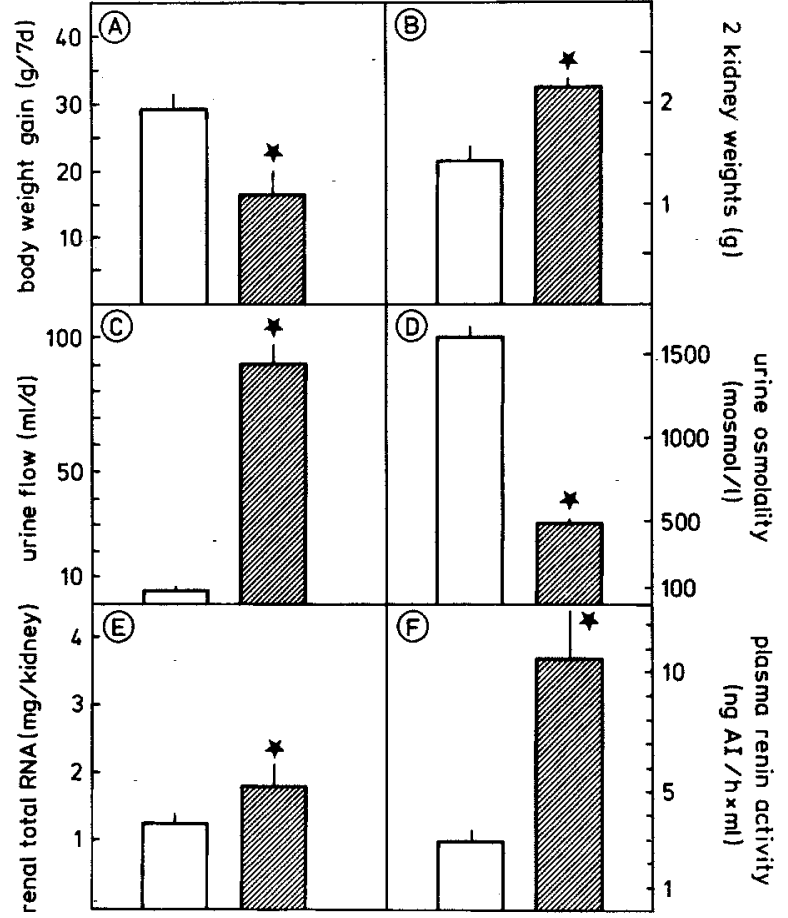

Fig. 2. Body weight gains (A), kidney weights (B), urine flow rates (C), urine osmolality (D), total renal RNA (E) and plasma renin activity (F) in vehicle- (open bars) and furosemide-treated (hatched bars) rats after 6 days of subcutaneous infusion. Data are means \pm SEM of ten $(\mathbf{A}, \mathbf{C}, \mathbf{D})$ or five $(\mathbf{B}, \mathbf{E}, \mathbf{F})$ animals each. $\star$, $P<0.05$ compared to vehicle. $A I$, angiotensin I

reached at somewhat reduced body weights of $168 \pm 6 \mathrm{~g}$ in furosemide-treated rats. This increase in kidney mass was paralleled by a similar increase of the yield of total RNA extractable from the kidneys (Fig. $1 \mathrm{E}$ ). Histological examination revealed that the increase of renal mass was primarily due to hypertrophy of the distal nephron including distal tubules, connecting tubules and collecting ducts (Fig. $3 \mathrm{~B}$ ).

As an estimate of the influence of furosemide treatment on renin secretion from the kidneys, plasma renin activities were determined. As shown in Fig. $2 \mathrm{~F}$ plasma renin activities were increased approximately threefold in furosemide-infused when compared with vehicletreated rats. To assess the effect of furosemide treatment on the expression of renin in the kidney two complementary methods were utilized, namely quantitative morphometry of renal areas immunoreactive for renin and semiquantification of renin mRNA by sensitive RNase protection. As shown in Fig. 4 there was an obvious increase of both intensity and extent of renin immunoreactivity in kidney section from furosemide-treated rats. Quantitative analyses revealed an $80 \%$ increase in the renin-positive areas in afferent arterioles at the vascular poles (Fig. 5). There was, moreover, also an increase of renin-positive areas in blood vessels not in contact with glomeruli. These areas increased from $141 \pm 20 \mu \mathrm{m}^{2} /$ $\mathrm{mm}^{2}$ in vehicle-treated rats to $247 \pm 38 \mu \mathrm{m}^{2} / \mathrm{mm}^{2}$ in furosemide-treated animals (Fig. 5).

RNase protection assays for renin mRNA on total RNA isolated from the right kidneys of all animals were 

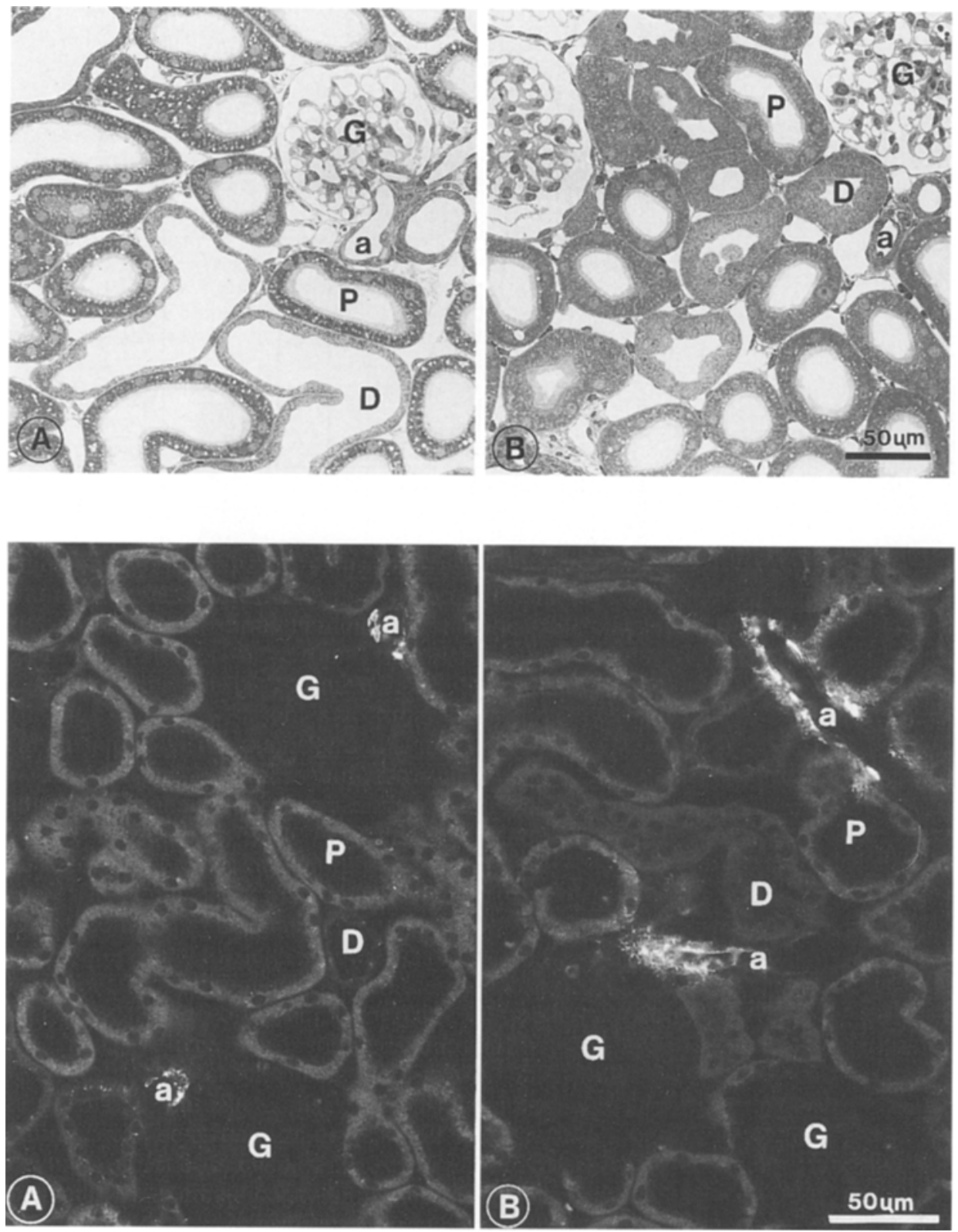

Fig. 3. Representative light photomicrographs of kidney sections from a rat infused with vehicle (A) and furosemide (B). $G$, glomerulus; $D$, distal tubule, $P$, proximal tubule; $a$, afferent arteriole

Fig. 4 A, B. Representative epifluorescence photomicrographs of rat kidney sections treated with rat renin antiserum. A Vehicle-treated rats; $\boldsymbol{B}$ furosemide-treated rats. $G$, glomerulus; $D$, distal tubule; $P$, proximal tubule; $a$, afferent arteriole performed using a 296-base-pair antisense RNA probe of rat preprorenin mRNA. Figure 6 shows an autoradiograph of such an RNase protection assay for control and furosemide-treated rats. For comparison and quantification a $20-\mu \mathrm{g}$ aliquot from a pool of total RNA isolated from 12 kidneys of six normal adult male rats was coanalysed on the gel as an external standard. It is evident from Fig. 6 that renin mRNA increased in the kidneys from furosemide-treated rats. For further quantification, protected fragments were excised from the dried gels and measured by $\beta$ counting. After background subtraction the radioactivity of each band was related to that of the external standard RNA and expressed as a percentage of the standard. Average renin mRNA levels that were quantified in this way in the right kidneys of control and furosemide-infused rats are illustrated in Fig. 7. There we found an $80 \%$ increase of the abundance of renin mRNA in the kidneys of furosemide-infused when compared with vehicle-treated rats. Taking into account that the yield of total RNA from kidneys of furosemidetreated rats was significantly increased (Fig. 2 E), it was calculated that the total renal amount of renin mRNA was increased by $120 \%$ in response to furosemide treatment (Fig. 7).

For comparison the abundance of rat cytoplasmic $\beta$ actin mRNA also was analysed in the RNA samples isolated from the kidneys of furosemide- and vehicletreated rats. As shown in Fig. 8 there was no difference of the abundance of actin mRNA between the kidneys of the two experimental groups.

\section{Discussion}

While the regulatory role of salt transport by the macula densa on the control of renin secretion from neighbour- 


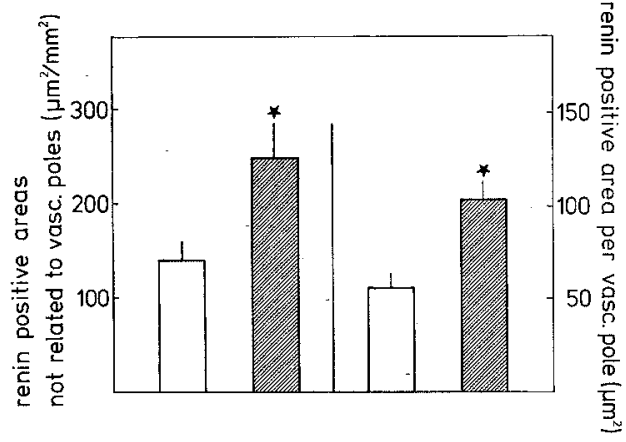

Fig. 5. Right: renin-immunoreactive areas per vascular pole (i. e. renin index) in rat kidney sections from vehicle- (open bars) and furosemide-infused (hatched bars) rats. Data are means \pm SEM of five animals each. $\star, P<0.05$ versus vehicle. Left: renin-immunoreactive areas not related to vascular poles given as a ratio of the total area examined $\left(\mu \mathrm{m}^{2}\right.$ per $\left.\mathrm{mm}^{2}\right)$ for vehicle- and furosemide-treated rats. Data are means \pm SEM of five rats each. $\star$, $P<0.05$ versus vehicle

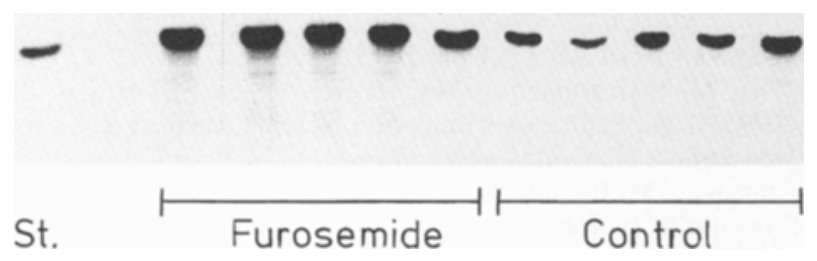

Fig. 6. Autoradiograph of an RNase protection assay for rat renin mRNA using total RNA extracted from the right kidneys of five furosemide- and five vehicle-infused rats; $20 \mu \mathrm{g}$ total RNA was analysed in each sample. The standard (St.) was prepared as described in Materials and methods

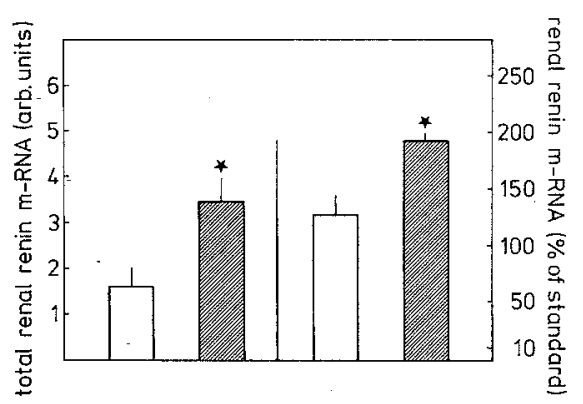

Fig. 7. Right: abundance of renin mRNA in right kidneys from vehicle- (open bars) and furosemide-infused (hatched bars) rats, expressed as a percentage of the standard RNA. Data are means \pm SEM of five rats each. $\star, P<0.05$ versus vehicle. Left: total renin mRNA in the right kidneys of vehicle- and furosemideinfused rats calculated from the abundance of renin mRNA and the yield of total RNA extractable from the kidneys. Values were calculated as (cpm sample/cpm standard) $\times$ yield of total RNA (in $\mu \mathrm{g})$ from the respective kidney and are given in arbitrary units. Data are means \pm SEM of five rats each. $\star, P<0.05$ versus vehicle

ing juxtaglomerular cells has been firmly established [8], the influence of the macula densa on the expression of renin is still unknown. As an experimental approach to elucidate a possible role of the macula densa in the control of renin expression we chose a chronic infusion of

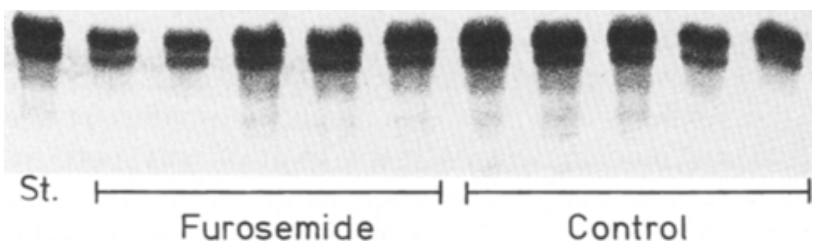

Fig. 8. Autoradiograph of RNase protection assays for rat $\beta$-actin mRNA using total RNA from the right kidneys of five furosemideand five vehicle-infused rats. $2.5 \mu \mathrm{g}$ total RNA was analysed in each sample. The standard (St.) was prepared as described in Materials and methods

furosemide into conscious rats. Furosemide, like other loop diuretics, has been found to block salt transport by the thick ascending limb of Henle (TALH) and by the macula densa cells [24] and, in consequence, to interrupt the macula densa signalling to juxtaglomerular cells and also to contractile vascular smooth muscle cells in the afferent arterioles [2].

A major side-effect of furosemide with relevance for the renin system is the induction of severe salt depletion and extracellular volume contraction if the salt and water losses are not compensated. To avoid extracellular volume contraction in our experiments we have, therefore, allowed the animals to have free access to water and salt, a regimen that leads to a positive sodium balance during chronic furosemide infusion [13]. As a consequence, the animals grew during furosemide treatment in spite of their enormous daily urine output, which amounted to more than $50 \%$ of the body mass of the animals. Probably as a functional compensation to increase the renal capacity for salt and water reabsorption, the distal nephrons markedly hypertrophied in furosemidetreated animals, a phenomenon that has already been described in detail [14].

Chronic furosemide infusion led to an enhancement of renin secretion as indicated by the elevated values of plasma renin activity (Fig. 2 F). Stimulation of renin secretion by furosemide has previously been described in experiments in vivo [15] and in vitro [17]. This effect has been attributed to the disinhibition of renin secretion induced by a block of the TALH and macula densa salt transport $[2,8,17]$.

The enhancement of renin secretion observed in our study was associated with an increase of the amount of immunoreactive renin in the kidneys (Fig. 5), suggesting an increase of renin synthesis during furosemide treatment. The finding of increased renin mRNA levels in these kidneys (Fig. 7) supports this conclusion and, moreover, suggests that the influence of furosemide treatment on renin synthesis primarily acts at the level of the renin mRNA rather than on the translational efficacy. Our morphological examinations, furthermore, suggest that furosemide infusion also led to an increase of the number of renin-positive cells. In furosemidetreated animals, renin-positive cells were found to extend more proximally along the afferent arteriole than in controls. Thus, the increase of renin mRNA during furosemide treatment may reflect both stimulation of the rate of renin synthesis in individual cells and a recruit- 
ment of cells not involved in renin synthesis under control conditions.

One must consider whether the effect of furosemide on the renin system was due to the inhibition of the TALH and macula densa salt transport or was more related to a secondary effect such as the strong diuresis, changes in sodium balance or changes of blood pressure. Although we cannot definitively rule out these possibilities from our experiments, they appear less likely in view of the salt and water substitution, which has been found to prevent extracellular volume contraction and falls of the blood pressure [13, 27], which is also in accordance with our recent observations in furosemidetreated rats with intact adrenal glands (Schricker and Kurtz, unpublished observation).

Also conceivable would be a linkage of the renin expression to the compensatory growth of the kidneys (Fig. 2B). Recent investigations, however, have revealed that compensatory renal growth is associated with a decrease of renin expression [21] and not with an increase as observed in this study.

One could furthermore imagine that the enhancement of renin expression may be secondary to the stimulation of renin secretion. An increased plasma renin activity and in consequence an increase of levels of circulating angiotensin II, however, would be expected to suppress rather than to enhance renin expression in the kidney $[12,25]$. An increase of renin expression as a direct consequence of stimulated renin secretion on a cellular level also appears less likely, because there is no obligatory linkage between renin secretion and renin synthesis in renal juxtaglomerular cells [16].

Taken together, it appears more likely that the stimulatory effects of furosemide on renin secretion and renin expression were related to the inhibition of tubular salt transport. This assumption raises the question of the mediation of these effects. Although several vasoconstrictor mediators such as adenosine, angiotensin II or thromboxane have been considered as candidates for the socalled macula densa mechanism, the signal transduction process still awaits identification [2]. Also prostaglandins, in particular $\mathrm{PGE}_{2}$, have been considered in this context, because it has been observed that inhibition of TALH and macula densa salt transport is associated with an enhanced renal medullary release of $\mathrm{PGE}_{2}$ (for review $[9,15])$. Since this prostaglandin is stimulatory for renin secretion [8], it is conceivable, although not yet demonstrated, that $\mathrm{PGE}_{2}$ could also stimulate renin gene expression. Considering also more recent findings, however, on the effects of furosemide on the macula densa $[11,17,19]$, it appears more likely that renal medullary $\mathrm{PGE}_{2}$ are not essentially required for the effect of furosemide on macula densa signalling.

Irrespective of the molecular link between salt transport and renin expression, our findings may suggest that inhibition of salt transport by the thick ascending limb of Henle, including the macula densa, stimulates not only the secretion but also the expression of renin in the kidney. Under this assumption we would postulate that the as yet unidentified macula densa signal not only reg- ulates exocytosis of renin granules but probably also the expression of the renin gene.

Acknowledgements. We thank R. Metzger, Heidelberg, Germany, for providing us with the rat preprorenin cDNA, P. Ratcliffe, Oxford, UK, for providing us with rat $\beta$-actin cDNA and T. Inagami, Nashville, USA, for the generous gift of the renin antiserum. The expert technical and graphical assistance provided by K. H. Götz, M. Hamann, U. Holzapfel and M. Müller and the secretarial help provided by $\mathrm{H}$. Trommer are gratefully acknowledged. This study was financially supported by a grant from the Deutsche Forschungsgemeinschaft (AZ Ku 859/2-1) and the Swiss National Foundation (31-24010.92).

\section{References}

1. Barrett GL, Morgan TO, Alcorn D (1990) Stimulation of renin synthesis in the hydronephrotic kidney during sodium depletion. Pflügers Arch 415:774-776

2. Briggs JP, Lorenz JN, Weihprecht H, Schnermann J (1991) Macula densa control of renin secretion. Renal Physiol Biochem 14:164-174

3. Burnham CE, Hawelu-Johnson CL, Frank BM, Lynch KR (1987) Molecular cloning of rat renin cDNA and its gene. Proc Natl Acad Sci USA 84:5605-5609

4. Chen M, Schnermann J, Malvan RL, Killen PD, Briggs JP (1993) Time course of stimulation of renal renin m-RNA by furosemide. Hypertension $21: 36-41$

5. Chirgwin JM, Przybla AE, MacDonald RJ, Rutter WJ (1979) Isolation of biologically active ribonucleic acid from sources enriched for ribonucleases. Biochemistry 18:5294-5299

6. Dawson T, Gandhi R, Le Hir M, Kaissling B (1989) Ecto-5'nucleotidase: localization in rat kidney by light microscopic histochemical and immunohistochemical methods. J Histochem Cytochem 37:39-47

7. Dzau VJ, Burt DW, Pratt RE (1988) Molecular biology of the renin-angiotensin system. Am J Physiol 255:F 563-F 573

8. Hackenthal E, Paul M, Ganten D, Taugner R (1990) Morphology, physiology, and molecular biology of renin secretion. Physiol Rev 70:1067-1116

9. Henrich WL (1981) Role of prostaglandins in renin secretion. Kidney Int 19:822-830

10. Ingelfinger JR, Pratt RE, Ellison K, Dzau VJ (1986) Sodium regulation of angiotensinogen mRNA expression in rat kidney cortex and medulla. J Clin Invest 78:1311-1315

11. Itoh S, Carretero OA (1985) Role of the macula densa in renin release. Hypertension $7: \mathrm{I}-49-\mathrm{I}-54$

12. Johns DW, Peach MJ, Gomez RA, Inagami T, Carey RM (1990) Angiotensin II regulates renin gene expression. Am J Physiol 259:F 882-F 887

13. Kaissling B, Stanton BA (1988) Adaptation of distal tubule and collecting duct to increased sodium delivery. I. Ultrastructure. Am J Physiol 255:F 1256-F 1268

14. Kaissling B, Bachmann S, Kriz W (1985) Structural adaptation of the distal convoluted tubule to prolonged furosemide treatment. Am J Physiol 248: F 374-F 381

15. Keeton K, Campbell WB (1981) The pharmacologic alteration of renin release. Pharmacol Rev 31:81-227

16. Kurtz A, Della Bruna R (1991) Determinants of renin secretion and renin synthesis in isolated mouse juxtaglomerular cells. Kidney Int 39:S 13-S 15

17. Lorenz JN, Weihprecht H, Schnermann J, Skott O, Briggs JP (1991) Renin release from isolated juxtaglomerular apparatus depends on macula densa chloride transport. Am J Physiol 260:F 486-F 493

18. Ludwig G, Ganten D, Murakami K, Fasching U, Hackenthal E (1987) Relationship between renin mRNA and renin secretion in adrenalectomized, salt depleted or converting enzyme inhibitor-treated rats. Mol Cell Endocrinol 50:223-229 
19. Martinez-Maldonado M, Gely R, Tapia E, Benabe JE (1990) Role of macula densa in diuretics-induced renin release. Hypertension 16:261-268

20. Moffet RB, McGowan RA, Gross KW (1986) Modulation of kidney renin messenger RNA levels during experimentally induced hypertension. Hypertension 8: 874-882

21. Pupilli C, Chevalier RL, Carey RM, Gomez RA (1992) Distribution and content of renin and renin mRNA in remnant kidney of adult rat. Am J Physiol 263:F 371-F 378

22. Ratcliffe PJ, Jones RW, Phillips RE, Nicholls LG, Bell JI (1990) Oxygen-dependent modulation of erythropoietin mRNA levels in isolated rat kidneys studied by RNase protection. J Exp Med 172:657-660

23. Samani MJ, Godfrey NP, Major JS, Brammar WJ, Swales JD (1989) Kidney renin mRNA levels in the early and chronic phases of two kidney, one-clip hypertension in the rat. $\mathbf{J}$ Hypertens $7: 105-112$
24. Schlatter E, Salomonsson M, Persson AEG, Greger R (1989) Macula densa cells sense the luminal $\mathrm{NaCl}$ concentration via furosemide-sensitive $\mathrm{Na}^{+} 2 \mathrm{Cl}^{-} \mathrm{K}^{+}$cotransport. Pflügers Arch 414:286-290

25. Schunkert H, Ingelfinger JR, Dzau VJ (1991) Evolving concepts of the intrarenal renin-angiotensin system in health and disease: contributions of molecular biology. Renal Physiol Biochem 14:146-154

26. Skott O, Briggs JP (1987) Direct demonstration of macula densa-mediated renin secretion. Science 237:1618-1620

27. Stanton BA, Kaissling B (1988) Adaptation of distal tubule and collecting duct to increased $\mathrm{Na}$ delivery. $\Pi$. $\mathrm{Na}^{+}$and $\mathrm{K}^{+}$ transport. Am J Physiol 255: F 1269-F 1275

28. Vander AJ, Miller R (1964) Control of renin secretion in the anesthetized dog. Am J Physiol 207:537-546

29. Weibel ER (1979) Stereological methods. In: Practical methods for morphometry, vol 1. Academic Press, New York 